\title{
Lore Hühn
}

\section{Kierkegaard und der Deutsche Idealismus}

\author{
Konstellationen des Übergangs
}

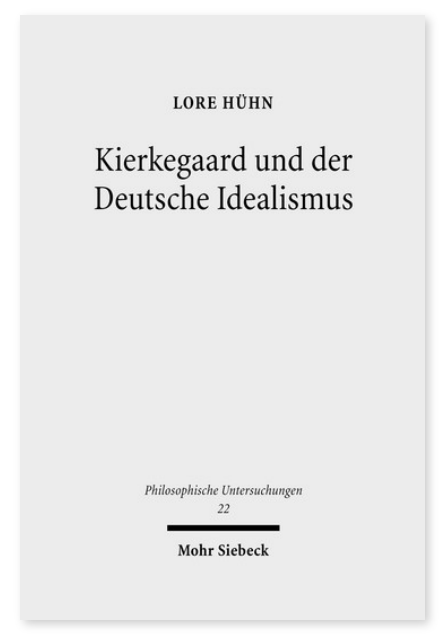

2009. XI, 272 Seiten. PhU 22

SBN 978-3-16-151333-6 DOI 10.1628/978-3-16-151333-6 eBook PDF $114,00 €$

ISBN 978-3-16-149582-3

Leinen $114,00 €$
Kierkegaards existenzphilosophischer und christologischer Ansatz ist aus einer Kritik an der Philosophie des Deutschen Idealismus, insbesondere derjenigen Hegels erwachsen. Diese Kritik organisiert Kierkegaard von der Fundamentaldifferenz her, die der späte Schelling gegen Hegels Vermittlungsdenken einer absoluten Vernunft wirkmächtig aufgeboten hat: die Fundamentaldifferenz zwischen einem im Möglichkeitsmodus des Denkbaren operierenden (negativen) Vernunftdiskurs und einer im Wirklichkeitsmodus der Erfahrung angesiedelten Positivität. Die von Schelling in seiner Spätphilosophie diagnostizierte Unmöglichkeit des logischen Denkens, über das »Was« einer Denkbestimmung zum »Dass« der Erfahrung zu kommen, ist von zentraler Bedeutung für Kierkegaards Interesse an Konstellationen des Übergangs. Den spekulativen Figuren des Zwischen, des Plötzlichen und des Augenblicks verleiht er eine neue, christologische Intelligibilität. Hierin konvergiert der Impuls der Kierkegaardschen Hegelkritik mit der Stoßrichtung des Ansatzes beim späten Fichte, nämlich beim praktischen Selbstvollzug des Einzelnen. Kierkegaard radikalisiert diese Ausrichtung auf ihre religiös-theologische Tiefenschicht hin, in welcher auf der einen Seite die Gottesbeziehung als die eigentliche Ursprungsdimension der Erfahrung, auf der anderen die subjektive Tat in ihrer unvordenklichen Selbstsetzung und zugleich Selbstverkehrung in den Blick genommen werden. Unverkennbar sind in dieser Ausrichtung Grundoptionen wirksam, die innerhalb der idealistischen Philosophie, teils zwischen Fichte und Schelling, teils in der Kritik des späteren Schelling an Hegel, aber auch an der eigenen Frühphilosophie kontrovers diskutiert wurden. Gegenüber diesen Diskussionen beschreitet Kierkegaard den Weg eines eigenen Übergangs in die Moderne.

»It is quite a task to untangle the web that somehow connects the Schelling, whose Naturphilosophie culminated in a break with his friend Fichte, to the Kierkegaard, whose remarkable dozen years of writing more or less begins in the period during which he is auditing Schelling's inaugural Berlin lectures. Such a task demands a fundamental rethinking of both the climate and the legacy of German idealism as such. I am happy to say that Lore Hühn's difficult but profound and surgically thorough and precise work [...] is impressively up to the task. [...] Dr. Hühn [...] one of the most thoughtful and illuminating readers of Schelling currently working in the Germanspeaking philosophical world« (S. 135).

Jason Wirth (Seattle University) in Research in Phenomenology 41 (2011).

Lore Hühn Geboren 1956; Studium der Philosophie, Germanistik und Politologie in Marburg und an der Freien Universität Berlin; 1993 Promotion; 2003 Habilitation; seit 2003 Professorin für Philosophie an der Albert-Ludwigs-Universität Freiburg; seit 2007 Präsidentin der Internationalen Schelling-Gesellschaft.

Jetzt bestellen:

https://mohrsiebeck.com/buch/kierkegaard-und-der-deutsche-idealismus-9783161513336?no cache=1

order@mohrsiebeck.com

Telefon: +49 (0)7071-923-17

Telefax: $+49(0) 7071-51104$ 